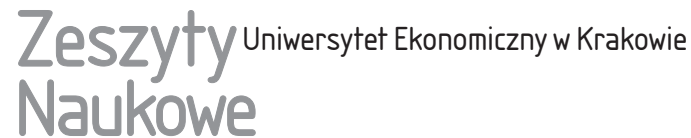

\section{Zawartość informacyjna sprawozdań finansowych jednostek sektora finansów publicznych}

\section{Streszczenie}

Sektor publiczny w większości krajów odgrywa ważną rolę w gospodarce. Jednostki sektora publicznego gromadzą dochody publiczne oraz wydatkują środki na zadania często niezyskowne, lecz niezbędne dla prawidłowego funkcjonowania społeczeństwa. Co ważne, kwoty środków pieniężnych uczestniczące w tych operacjach stanowią istotną część transferów całej gospodarki. Z tego względu na jednostkach sektora finansów publicznych ciąży obowiązek prowadzenia ksiąg rachunkowych zgodnie z przepisami ustawy o rachunkowości, jak również przepisami szczególnymi, dostosowanymi do specyfiki sektora publicznego.

Jednym z obowiązków wynikającym z ustawy o rachunkowości jest obowiązek prezentowania sytuacji majątkowej i finansowej w postaci sprawozdań finansowych. W przypadku jednostek sektora finansów publicznych obowiązek ten został rozszerzony o konieczność sporządzania sprawozdań budżetowych, których głównym celem jest zaprezentowanie aktualnej sytuacji jednostki w zakresie realizowanych dochodów i wydat-

Bartłomiej Wrona, Uniwersytet Ekonomiczny w Krakowie, Wydział Finansów i Prawa, Katedra Rachunkowości Finansowej, ul. Rakowicka 27, 31-510 Kraków, e-mail: wronab@uek.krakow.pl Halina Rechul, Państwowa Wyższa Szkoła Zawodowa w Nowym Sączu, Instytut Ekonomiczny, ul. Jagiellońska 61, 33-300 Nowy Sącz, e-mail: rechulh@uek.krakow.pl

Małgorzata Szulc, Uniwersytet Ekonomiczny w Krakowie, Wydział Finansów i Prawa, Katedra Rachunkowości Finansowej, ul. Rakowicka 27, 31-510 Kraków, e-mail: malgorzata.szulc@uek. krakow.pl 
ków budżetowych. System sprawozdawczości budżetowej obecnie jest wykorzystywany w zarządzaniu finansami jednostek sektora finansów publicznych głównie w okresach krótkich. Sprawozdania finansowe, które mogą być przedmiotem analizy finansowej i wspierać podejmowanie decyzji długoterminowych, są wykorzystywane dosyć rzadko.

Celem artykułu jest zaprezentowanie sprawozdawczości finansowej jednostek sektora finansów publicznych, wskazanie możliwości wykorzystania w rachunkowości międzynarodowych standardów rachunkowości sektora publicznego oraz omówienie wybranych aspektów analizy finansowej i jej wykorzystania.

Słowa kluczowe: sektor publiczny, sprawozdawczość finansowa, sprawozdawczość budżetowa, analiza finansowa.

Klasyfikacja JEL: M41.

\section{Wprowadzenie}

Działalność jednostek sektora finansów publicznych polega w szczególności na: gromadzeniu dochodów publicznych i ich wydatkowaniu, finansowaniu potrzeb pożyczkowych budżetu państwa, zaciąganiu zobowiązań angażujących środki publiczne, zarządzaniu środkami i długiem publicznym oraz rozliczeniach z budżetem Unii Europejskiej (Ustawa z dnia 27 sierpnia 2009 r....).

Podmioty zaliczane do sektora finansów publicznych dokonują szeregu czynności prawnych, które skutkują określonymi rezultatami ekonomicznymi mającymi wpływ nie tylko na ten sektor, ale również na pozostałe podmioty funkcjonujące w realiach wspólnego rynku. Systemem, który dostarcza informacji o gospodarowaniu środkami w procesie realizacji zadań przez podmioty sektora publicznego, jest rachunkowość tych podmiotów.

Jednostki sektora finansów publicznych stosują szczególne zasady rachunkowości, planowania, a także sprawozdawczości. Związane jest to z gospodarowaniem środkami publicznymi, środkami pochodzącymi z budżetu Unii Europejskiej oraz z innych źródeł zagranicznych.

Na sprawozdawczość w sektorze finansów publicznych składa się sprawozdawczość finansowa oraz sprawozdawczość budżetowa. Regulacje dotyczące sprawozdawczości finansowej zawarte są przede wszystkim w ustawie o rachunkowości, ustawie o finansach publicznych oraz rozporządzeniu w sprawie szczególnych zasad rachunkowości oraz planów kont dla budżetu państwa, budżetów jednostek samorządu terytorialnego, jednostek budżetowych, samorządowych zakładów budżetowych, państwowych funduszy celowych oraz państwowych jednostek budżetowych mających siedzibę poza granicami Rzeczypospolitej Polskiej.

Podmioty sektora prywatnego w sytuacjach nieuregulowanych przepisami ustawy o rachunkowości mają możliwość korzystania z krajowych standardów rachunkowości (KSR), a w przypadku braku odpowiedniego KSR mają zastoso- 
wanie międzynarodowe standardy rachunkowości. Dla podmiotów sektora finansów publicznych opracowano międzynarodowe standardy rachunkowości sektora publicznego (International Public Sector Accounting Standards - IPSAS), które są skutkiem dążenia do ujednolicenia zasad rachunkowości w sektorze publicznym.

Celem opracowania jest przedstawienie szczególnych zasad rachunkowości oraz sprawozdawczości finansowej w jednostkach sektora finansów publicznych z uwzględnieniem rozwiązań międzynarodowych, a także zaprezentowanie możliwości wykorzystania analizy finansowej w jednostkach budżetowych, uwzględniającej specyfikę sektora oraz odejście od administrowania budżetem na rzecz bardziej efektywnego zarzadzania środkami publicznymi.

\section{Wybrane problemy zarządzania finansami w jednostkach sektora finansów publicznych}

W sektorze gospodarczym w ostatnich latach widoczny jest wzrost roli i znaczenia sektora publicznego, zwłaszcza w zakresie wpływu kreowanych przez ten sektor przepływów pieniężnych. Od wielu lat postuluje się podnoszenie efektywności wydatkowanych środków oraz racjonalizację wydatków budżetowych. Z drugiej strony u osób zarządzających jednostkami budżetowymi zauważalna jest tendencja do dokonywania wydatków w sposób nie zawsze przemyślany i celowy, nie poparty klasycznym rachunkiem opłacalności inwestycji. Sytuacje te można zauważyć zwłaszcza w jednostkach samorządu terytorialnego, w których często interes związany z bieżącymi celami politycznymi przeważa nad celem społecznym. Widoczna jest presja na wykonywanie zadań inwestycyjnych, kosztochłonnych, które nie zawsze przynoszą oczekiwane korzyści ekonomiczne. Typowym przykładem są baseny, pływalnie i aquaparki, których powstanie wiąże się z wydatkowaniem ogromnych kwot środków publicznych, zaś ich późniejsze funkcjonowanie nie przynosi zadowalających dochodów. W niektórych sytuacjach uzyskiwane dochody nie pozwalają na pokrycie bieżących kosztów utrzymania tych obiektów.

Jednostki budżetowe prowadzą gospodarkę finansową opartą na dwóch metodach finansowania. Metoda netto zakłada, że jednostka z osiąganych przychodów pokrywa koszty swojej działalności. Ta metoda zbliżona jest do klasycznej metody gospodarki rynkowej. Powszechniejszą metodą jest metoda brutto, która zakłada brak możliwości samofinansowania jednostki. Musi ona otrzymać środki na wydatki, których chce dokonać, zaś ewentualne dochody zwrócić do budżetu. Środki, które zostały otrzymane, w przypadku ich niewykorzystania muszą zostać zwrócone, co często doprowadza do sytuacji, że wydatkowana jest cała kwota środków, nawet jeśli nie byłoby takiej konieczności. W jednostkach tych poku- 
tuje przekonanie, że zwrócenie środków spowoduje obniżenie kwot otrzymanych w kolejnym roku.

Na sektorze publicznym spoczywa też coraz więcej zadań. Katalog ten wciąż się powiększa i, co istotne, nie zawsze jednostki budżetowe otrzymują na zlecone im zadania wystarczające środki z budżetu centralnego. Przykładami mogą być oświata, która w większości budżetów jednostek samorządu terytorialnego wymaga dodatkowego finansowania środkami własnymi, opieka społeczna, kultura i sport.

Jednostki budżetowe, prowadząc działalność, swoje finansowanie opierają na budżecie, będącym zestawieniem dochodów i wydatków oraz przychodów i rozchodów. Budżet musi zostać zbilansowany, co oznacza, że na wydatki dokonywane przez te jednostki musi istnieć pokrycie w dochodach. Praktyka pokazuje, że sytuacja taka ma miejsce niezmiernie rzadko, istnieje więc konieczność zadłużania się, skutecznie blokowana przepisami ustawy o finansach publicznych, których celem jest niedoprowadzenie do bankructwa jednostki samorządu terytorialnego. Możliwość sfinansowania deficytu budżetowego np. kredytami bankowymi ocenia Regionalna Izba Obrachunkowa (RIO), wydając opinię o projekcie uchwały budżetowej. Od 2014 r. nowelizacją ustawy o finansach publicznych wprowadzono indywidualny wskaźnik zadłużenia (IWZ), którego celem miało być zdyscyplinowanie coraz bardziej zadłużających się jednostek.

Nieuzyskanie przez jednostkę pozytywnej opinii o możliwości wykonania budżetu może skutkować wprowadzeniem nadzoru komisarycznego. Uznaje się bowiem w takiej sytuacji, że jednostka utraciła zdolność do prowadzenia bieżącej działalności ze względu za zbyt duże zadłużenie. Ma to dwojakie skutki. Po pierwsze, jednostki budżetowe monitorują poziom maksymalnego zadłużenia z uwzględnieniem wskaźników, których przekroczenie naraziłoby je na brak pozytywnej opinii RIO. W wielu sytuacjach dostosowuje się wydatki budżetowe do granicznych wartości wskaźników. Tę sytuację można ocenić pozytywnie, jest to działanie dozwolone, związane z zarząadzaniem finansami tych podmiotów. $\mathrm{O}$ wiele gorsza w skutkach jest jednak sytuacja druga, w której jednostki próbują omijać przepisy ustawy o finansach publicznych przy wykorzystaniu niestandardowych instrumentów finansowych, np. finansowania kapitałowego, leasingu zwrotnego i sprzedaży zwrotnej, subrogacji czy płatności ratalnych. Wiąże się to z niebezpieczeństwem utraty płynności finansowej przez te jednostki, a w praktyce związane jest z ukrywaniem lawinowo rosnącego zadłużenia.

Muszą więc istnieć sposoby kontrolowania tych instrumentów, ale - co najważniejsze - także posiadania informacji o faktycznym zadłużeniu jednostek sektora publicznego. Istnieją realne obawy, że prezentowana sytuacja „kreatywnego” ukrywania zadłużenia może doprowadzić do kolejnego kryzysu gospodarczego. Stabilność finansowa instytucji rządowych i samorządowych powinna być 
traktowana jako kwestia priorytetowa. Narzędziem, za pomocą którego można dokonywać realnej oceny sytuacji finansowej jednostek budżetowych, jest system sprawozdawczości finansowej i budżetowej oparty na rzetelnie prowadzonych księgach rachunkowych. Problemem jest to, że rachunkowość wykonania budżetu oparta jest na zasadzie kasowej (faktyczne przepływy pieniężne), zaś nadzór budżetowy Unii Europejskiej opiera się na standardzie ESA 95 wymagającym ujęcia memoriałowego.

Konieczne jest więc dostosowanie rachunkowości i sprawozdawczości budżetowej i finansowej do powyższej normy. Służyć temu mają międzynarodowe standardy rachunkowości sektora publicznego, będące jedynym uznanym międzynarodowym systemem prowadzenia rachunkowości jednostek sektora finansów publicznych.

\section{Kierunki standaryzacji rachunkowości jednostek sektora finansów publicznych}

Rachunkowość jednostek sektora publicznego w krajach Europy jest bardzo zróżnicowana, zarówno na poziomie międzynarodowym, jak i w obrębie poszczególnych krajów. Różnorodność ta dotyczy zasad wyceny składników majątkowych, a także ujawniania informacji w sprawozdaniach finansowych i budżetowych. W rachunkowości sektora publicznego w krajach europejskich stosowana jest w różnym wymiarze zasada kasowa i zasada memoriałowa rachunkowości (Adamek-Hyska 2011). Zgodnie z zasadą kasową w systemie rachunkowym ujmowane są tylko rzeczywiste wpływy i wydatki, natomiast zasada memoriałowa nakazuje przedstawienie w księgach operacji nierozliczonych, wprowadzając pojęcia należności i zobowiązań, co umożliwia pełniejszą prezentację informacji (Gołębiowski 2016). Tworzenie budżetu według metody kasowej oraz sporządzanie sprawozdań finansowych metodą memoriałową może wprowadzać chaos w procesie zarządzania finansami publicznymi (Winiarska i Kaczurak-Kozak 2013). Coraz częściej wskazuje się zatem na potrzebę dostarczania porównywalnych informacji poprzez sprawozdania finansowe.

Efektem podjętych działań w kierunku standaryzacji rachunkowości w sektorze publicznym są międzynarodowe standardy rachunkowości sektora publicznego. Standardy te wydawane są przez Radę ds. Międzynarodowych Standardów Rachunkowości Sektora Publicznego (International Public Sector Accounting Standards Board - IPSASB), działającą w ramach struktur Międzynarodowej Federacji Księgowych (International Federation of Accountants - IFAC). Misją Rady ds. Międzynarodowych Standardów Rachunkowości Sektora Publicznego jest tworzenie wysokiej jakości standardów rachunkowości stosowanych przez 
podmioty sektora publicznego z całego świata w celu przygotowania sprawozdań finansowych ogólnego przeznaczenia. IPSASB rozwija głównie standardy dotyczące zasady memoriałowej. Wynika to przede wszystkim z coraz większego podobieństwa rachunkowości stosowanej w sektorze publicznym i w sektorze prywatnym (Winiarska i Kaczurak-Kozak 2013).

Dotychczas Rada wydała 40 międzynarodowych standardów rachunkowości sektora publicznego oraz 3 rekomendacje w zakresie tzw. dobrych praktyk Recommended Practice Guideline, RPG (IPSAS in Your Pocket... 2017).

Międzynarodowe standardy rachunkowości sektora publicznego mają pomóc w tworzeniu nowych lub poprawić istniejące już standardy krajowe, tak aby zapewnić większą porównywalność danych dostarczanych w ramach systemu rachunkowości w różnych krajach.

Elementem standaryzacji rachunkowości sektora publicznego są tworzone obecnie europejskie standardy rachunkowości sektora publicznego (European Public Sector Accounting Standards - EPSAS) na bazie międzynarodowych standardów rachunkowości sektora publicznego.

W celu praktycznego wykorzystania IPSAS jako podstawy budowania przyszłych standardów EPSAS podzielono je na trzy kategorie standardów (Kościelniak 2016):

- standardy IPSAS nadające się do wdrożenia bez zmian bądź z minimalnymi zmianami,

- standardy IPSAS wymagające adaptacji lub selektywnego podejścia,

- standardy IPSAS wymagające uzupełnienia przed wdrożeniem.

Wdrożenie EPSAS w krajach Unii Europejskiej, w tym także w Polsce, będzie miało znaczący wpływ m.in. na sprawozdawczość finansową jednostek sektora finansów publicznych.

\section{Sprawozdawczość finansowa w jednostkach sektora finansów publicznych}

Obowiązek sporządzania sprawozdania finansowego spoczywa na każdej jednostce podlegającej ustawie o rachunkowości. W przypadku jednostek zaliczanych do sektora finansów publicznych ich sporządzanie odbywa się zgodnie z zasadami zawartymi w ustawie o rachunkowości oraz na podstawie rozporządzenia w sprawie szczególnych zasad rachunkowości oraz planów kont (Sprawozdawczość finansowa i budżetowa... 2016).

Regulacje w obszarze sprawozdawczości finansowej jednostek sektora finansów publicznych ujęte są w rozporządzeniu Ministra Finansów z dnia 5 lipca 2010 r. w sprawie szczególnych zasad rachunkowości oraz planów kont dla budżetu 
państwa, budżetów jednostek samorządu terytorialnego, jednostek budżetowych, samorządowych zakładów budżetowych, państwowych funduszy celowych oraz państwowych jednostek budżetowych mających siedzibę poza granicami Rzeczypospolitej Polskiej (Rozporządzenie Ministra Finansów z dnia 5 lipca 2010 r....), które zostało zmienione m.in. rozporządzeniem Ministra Finansów z dnia 2 listopada 2015 r. oraz rozporządzeniem Ministra Rozwoju i Finansów z dnia 29 grudnia $2016 \mathrm{r}$.

Ta ostania nowelizacja przepisów rozporządzenia wynikała z konieczności dostosowania zasad rachunkowości w szczególności do zmian wynikających z nowo wprowadzonych przepisów, w tym m.in.:

- przepisów ustrojowych jednostek samorządu terytorialnego wprowadzonych ustawą o zmianie ustawy o samorządzie gminnym oraz niektórych innych ustaw (Ustawa z dnia 25 czerwca 2015 r....),

- rozporządzeniem Parlamentu Europejskiego i Rady (UE) w sprawie identyfikacji elektronicznej i usług zaufania w odniesieniu do transakcji elektronicznych na rynku wewnętrznym (Rozporządzenie Parlamentu Europejskiego i Rady (UE) nr 910/2014 z dnia 23 lipca 2014 r....).

Należy podkreślić, że efektem prac przygotowawczych prowadzonych przez Komisję Europejską ma być standaryzacja rachunkowości w jednostkach sektora publicznego w całej Unii Europejskiej polegająca na opracowaniu europejskich standardów rachunkowości sektora publicznego. Pierwszym etapem wdrożenia tych prac ma być przygotowanie przez kraje członkowskie tzw. bilansu otwarcia obejmującego wszystkie aktywa i zobowiązania sektora general government. Przepisy znowelizowanego rozporządzenia wychodzą naprzeciw działaniom Komisji Europejskiej zmierzającym do standaryzacji rachunkowości w jednostkach sektora publicznego w całej Unii Europejskiej.

Na dzień zamknięcia ksiąg rachunkowych, inaczej nazywanym dniem bilansowym, jednostki budżetowe, urzędy jednostek samorządu terytorialnego oraz samorządowe zakłady budżetowe sporządzają jednostkowe sprawozdanie finansowe, które składa się z bilansu, rachunku zysków i strat (wariant porównawczy) oraz zestawienia zmian $w$ funduszu.

Państwowe jednostki budżetowe obsługujące dysponenta głównego i dysponentów środków budżetu państwa drugiego stopnia sporządzają łączne sprawozdania finansowe, będące sumą sprawozdań finansowych jednostek i placówek podległych dysponentom głównym części budżetowej i dysponentom środków budżetu państwa drugiego stopnia oraz własnego sprawozdania finansowego, z odpowiednim wyłączeniem wzajemnych rozliczeń dokonywanych między tymi jednostkami. Wyłączenia wzajemnych rozliczeń dotyczą w szczególności:

- wzajemnych należności i zobowiązań oraz innych rozrachunków o podobnym charakterze, 
- wyniku finansowego ustalonego na operacjach dokonywanych pomiędzy jednostkami.

Bilans jednostki budżetowej i samorządowego zakładu budżetowego stanowi podstawowy element sprawozdania finansowego. Należy jednak pamiętać, że jednostki te rozliczają się na odmiennych zasadach. Sposób rozliczania jednostki budżetowej i samorządowego zakładu budżetowego wobec budżetu organu prowadzącego przedstawiono $\mathrm{w}$ tabeli 1 .

Tabela 1. Sposób rozliczania jednostki budżetowej i samorządowego zakładu budżetowego wobec budżetu organu prowadzącego

\begin{tabular}{|c|c|}
\hline \multicolumn{1}{|c|}{ Jednostki budżetowe } & Samorządowe zakłady budżetowe \\
\hline - nie mają osobowości prawnej & - nie mają osobowości prawnej \\
- rozliczają się z budżetem organu prowadzą- & - rozliczają się z budżetem organu prowadzą- \\
cego metodą budżetowania brutto, która & cego metodą budżetowania netto, polegającą \\
polega na odprowadzaniu całości pobranych & na pokrywaniu kosztów prowadzonej dzia- \\
dochodów budżetowych na rzecz budżetu & łalności uzyskiwanymi w trakcie jej prowa- \\
organu prowadzącego oraz finansowaniu & dzenia przychodami \\
realizowanych wydatków budżetowych bez- & - wyposażone są w chwili ich utworzenia \\
pośrednio z budżetu jednostki samorządu & w niezbędne do prowadzenia działalności \\
terytorialnego w celu realizacji powierzo- & składniki majątku \\
nych jej zadań & - z budżetem organu prowadzącego rozliczają \\
- wyposażone są w majątek & się poprzez odprowadzenie na rzecz budżetu \\
- swoją działalność prowadzą na podstawie & jednostki samorządu terytorialnego nad- \\
przyznanego i zatwierdzonego planu finan- & wyżki środków obrotowych \\
sowego & - uprawnione są do otrzymywania dotacji \\
- mogą pozyskiwać składniki majątku & z budżetu jednostki samorządu terytorialnego \\
w ramach realizacji planu finansowego & - mogą pozyskiwać środki trwałe oraz war- \\
poprzez ich nabycie lub budowę, a także & tości niematerialne i prawne poprzez ich \\
w drodze nieodpłatnego przyjęcia & zakupy albo budowę \\
\hline
\end{tabular}

Źródło: (Niemiec 2017, s. 7).

Jednostki budżetowe i samorządowe zakłady budżetowe sporządzają bilans:

1) na dzień bilansowy, w terminie 3 miesięcy od dnia, na który zamyka się księgi rachunkowe,

2) w języku polskim i w walucie polskiej (dane prezentowane w groszach i złotych),

3) na podstawie danych wynikających z ksiąg rachunkowych (bilans podpisuje główny księgowy oraz kierownik danej jednostki).

Bilans jako podstawowa część sprawozdania finansowego jednostki zawiera informacje o stanie jej aktywów oraz pasywów na koniec okresu sprawozdawczego. Przedstawia dane o zasobach majątkowych i źródłach ich pochodzenia, więc znajdują w nim odzwierciedlenie skutki operacji finansowych i majątkowych realizowanych przez jednostkę w przeszłości. Wzór bilansu jednostki organiza- 
cyjnej sektora finansów publicznych został przedstawiony w załączniku nr 5 do rozporządzenia Ministra Finansów z dnia 5 lipca 2010 r., a jego układ oparty jest na wzorze bilansu jednostek objętych obowiązkiem stosowania ustawy o rachunkowości, innych niż banki i ubezpieczyciele (Rup 2017).

Bilans sporządza się na podstawie wyników działalności gospodarki finansowej i gospodarki majątkiem przedstawionych w ewidencji prowadzonej w księgach rachunkowych jednostki, a podstawą jego sporządzenia jest zestawienie obrotów i sald kont księgi głównej i sald kont pomocniczych na koniec roku obrotowego (Rup 2017).

Dane uzupełniające do bilansu zawierają informacje istotne dla oceny rzetelności i przejrzystości sytuacji finansowej i majątkowej jednostek budżetowych i samorządowych zakładów budżetowych. W załączniku nr 5 do rozporządzenia Ministra Finansów z dnia 5 lipca 2010 r. wskazano, że mają to być informacje dotyczące:

- umorzenia wartości niematerialnych i prawnych, umorzenia środków trwałych, umorzenia pozostałych środków trwałych,

- odpisy aktualizujące środki trwałe, odpisy aktualizujące środki trwałe w budowie, odpisy aktualizujące wartości niematerialne i prawne, odpisy aktualizujące należności.

Uzupełnieniem bilansu jest rachunek zysków i strat, w którym zawarte są wszystkie te wartości wynikowe, które wpływają na wynik bilansowy jednostki. Rachunek zysków i strat sporządzany jest najpóźniej do 31 marca następnego roku, a wykazywane w nim wartości powinny być przedstawione w złotych i groszach. Tak jak w przypadku bilansu rachunek zysków i strat podpisuje główny księgowy i kierownik jednostki.

Rachunek zysków i strat odzwierciedla zastosowany w ewidencji rachunkowej wariant obliczania wyniku finansowego. W jednostkach organizacyjnych sektora finansów publicznych niemających osobowości prawnej obowiązkowe jest stosowanie wariantu porównawczego obliczania wyniku finansowego. Wynika to ze wzoru rachunku zysków i strat określonego w załączniku nr 7 do rozporządzenia Ministra Finansów z dnia 5 lipca 2010 r. Należy podkreślić, że porównawczy wariant ustalania wyniku finansowego można stosować, gdy jednostka prowadzi ewidencję kosztów w układzie rodzajowym lub jednocześnie w układzie rodzajowym i kalkulacyjnym (Rup 2017).

Trzecim elementem rocznego sprawozdania finansowego jednostek budżetowych oraz samorządowych zakładów budżetowych jest zestawienie zmian w funduszu. Jest to sprawozdanie, które ukazuje przyczyny zwiększenia i zmniejszenia funduszu jednostki. Zestawienie zmian w funduszu jednostki obrazuje poniesione przez nią koszty i osiągnięte przychody, które zostały bezpośrednio zaksięgowane na fundusz własny jednostki. Zestawienie zmian w funduszu 
jednostki powinno odzwierciedlać księgowania prowadzone na koncie 800 „Fundusz jednostki” (Rup 2017).

Zestawienie zmian w funduszu sporządzane jest najpóźniej do 31 marca następnego roku, wykazywane w nim wartości przedstawiane są w złotych i groszach. Podpisuje je główny księgowy i kierownik jednostki, a wzór sprawozdania zawarty jest w załączniku nr 8 do rozporządzenia Ministra Finansów z dnia 5 lipca 2010 r.

Należy podkreślić, że sprawozdanie finansowe jest narzędziem pozwalającym na analizę danych finansowych, które przedstawia w uporządkowany i syntetyczny sposób. Zadaniem sprawozdań finansowych jest informowanie zainteresowane podmioty o sytuacji finansowej jednostki. Zawartość informacyjną elementów sprawozdania finansowego przedstawiono w tabeli 2.

Sprawozdanie finansowe jednostki samorządu terytorialnego częściowo odbiega od zasad ogólnych, ponieważ składa się ono z (Rozporządzenie Ministra Finansów z dnia 5 lipca 2010 r....):

- bilansu z wykonania budżetu jednostki samorządu terytorialnego,

- łącznego bilansu, obejmującego dane wynikające z bilansów samorządowych jednostek budżetowych i samorządowych zakładów budżetowych,

- łącznego rachunku zysków i strat, obejmującego dane wynikające z rachunku zysków i strat samorządowych jednostek budżetowych i samorządowych zakładów budżetowych,

- łącznego zestawienia zmian w funduszu, obejmującego dane wynikające z zestawień zmian w funduszu samorządowych jednostek budżetowych i samorządowych zakładów budżetowych.

Układ bilansu z wykonania budżetu jednostki samorządu terytorialnego zdecydowanie różni się od wersji z ustawy o rachunkowości, opartej na podziale aktywów na trwałe i obrotowe, a pasywów na kapitał (fundusz) własny oraz zobowiązania i rezerwy. Prezentowane natomiast są w takim bilansie informacje dotyczące procesów gromadzenia środków publicznych przez jednostkę samorządu terytorialnego oraz ich rozdysponowania. W aktywach bilansu z wykonania budżetu wykazywane są środki pieniężne, należności i rozliczenia oraz inne aktywa. W pasywach główne pozycje to zobowiązania, aktywa netto budżetu oraz inne aktywa.

Rachunkowość wykonania budżetu prowadzona jest według zasady kasowej w odniesieniu do dochodów i wydatków budżetowych. Do ewidencji przychodów i rozchodów budżetu stosuje się jednak zasadę memoriałową, co skutkuje występowaniem rozrachunków w ewidencji wykonania budżetu. Ta specyfika rachunkowości budżetu jednostek samorządu terytorialnego znalazła swoje odbicie we wzorze bilansu z wykonania budżetu tych jednostek. Należy podkreślić, że bilans z wykonania budżetu jest jedynym składnikiem sprawozdania finansowego sporządzonego na podstawie ksiąg rachunkowych wykonania budżetu (Rup 2017). 
Tabela 2. Zawartość informacyjna elementów sprawozdania finansowego

\begin{tabular}{|c|c|}
\hline Informacje & Wykorzystanie \\
\hline \multicolumn{2}{|c|}{ Bilans } \\
\hline $\begin{array}{l}\text { I. Majątek trwały } \\
\text { II. Majątek obrotowy } \\
\text { III. Kapitały (fundusze) własne } \\
\text { IV. Kapitały (fundusze) własne }\end{array}$ & $\begin{array}{l}\text { Do oceny: } \\
\text { - wielkości i struktury majątku } \\
\text { - wielkości i struktury źródeł finansowania } \\
\text { - kierunków wykorzystania źródeł finanso- } \\
\text { wania } \\
\text { - bezpieczeństwa finansowego }\end{array}$ \\
\hline \multicolumn{2}{|c|}{ Rachunek zysków i strat } \\
\hline $\begin{array}{l}\text { I. Przychody } \\
\text { II. Koszty } \\
\text { III. Wynik finansowy brutto } \\
\text { IV. Obowiązkowe obciążenia wyniku finan- } \\
\text { sowego } \\
\text { V. Wynik finansowy netto }\end{array}$ & $\begin{array}{l}\text { Do oceny: } \\
\text { - poziomu i struktury przychodów } \\
\text { - poziomu i struktury kosztów } \\
\text { - wielkości i struktury wyniku finansowego } \\
\text { - wielkości obowiązkowych obciążeń wyniku } \\
\quad \text { finansowego }\end{array}$ \\
\hline \multicolumn{2}{|c|}{ Rachunek przepływów pieniężnych } \\
\hline $\begin{array}{l}\text { I. Przepływy z działalności operacyjnej } \\
\text { II. Przepływy z działalności inwestycyjnej } \\
\text { III. Przepływy z działalności finansowej }\end{array}$ & $\begin{array}{l}\text { Do oceny: } \\
\text { - obszarów generujących nadwyżkę pieniężną } \\
\text { - roli poszczególnych rodzajów działalności } \\
\text { w generowaniu nadwyżki pieniężnej (niedo- } \\
\text { boru pieniężnego) } \\
\text { - źródeł wpływów i kierunków wydatków }\end{array}$ \\
\hline \multicolumn{2}{|c|}{ Zestawienie zmian w kapitale (funduszu) własnym } \\
\hline $\begin{array}{l}\text { I. Kapitał (fundusz) własny na początek okresu } \\
\text { II. Zmiany kapitału (funduszu) własnego } \\
\text { III. Kapitał (fundusz) własny na koniec okresu }\end{array}$ & $\begin{array}{l}\text { Do oceny: } \\
\text { - wyniku finansowego netto } \\
\text { - zmian poszczególnych pozycji kapitału }\end{array}$ \\
\hline \multicolumn{2}{|c|}{ Informacja dodatkowa } \\
\hline $\begin{array}{l}\text { I. Rozwinięcie i uszczegółowienie informa- } \\
\text { cji zawartych w elementach sprawozdania } \\
\text { finansowego } \\
\text { II. Inne istotne informacje wykorzystywane do } \\
\text { oceny jednostki }\end{array}$ & $\begin{array}{l}\text { Do oceny: } \\
\text { - majątku jednostki i sposobów jego wyko- } \\
\text { rzystania } \\
\text { - przychodów i kosztów } \\
\text { - wpływów i wydatków } \\
\text { - zmian w kapitale (funduszu) własnym } \\
\text { - zdolności jednostki do kontynuowania dzia- } \\
\text { łalności }\end{array}$ \\
\hline
\end{tabular}

Źródło: (Sprawozdawczość finansowa i budżetowa... 2016, s. 124).

Przepisy rozporządzenia Ministra Finansów z dnia 5 lipca 2010 r. wskazują także na konieczność sporządzania łącznego sprawozdania jednostki samorządu terytorialnego, składającego się z łącznego bilansu, łącznego rachunku zysków i strat oraz łącznego zestawienia zmian w funduszu jednostki. 


\section{Wybrane aspekty analizy finansowej w jednostkach samorządu terytorialnego}

W literaturze przedmiotu analiza finansowa jest prezentowana najczęściej jako dział analizy ekonomicznej obok analizy techniczno-ekonomicznej i strategicznej (Analiza finansowa... 1996). Podział analizy ekonomicznej przedstawia rys. 1.

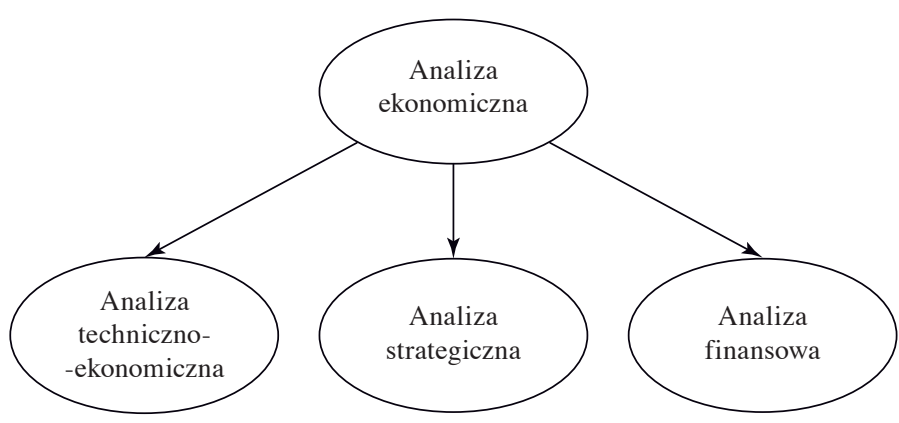

Rys. 1. Działy analizy ekonomicznej

Źródło: opracowanie własne.

Przyjmuje się, że analiza ekonomiczna polega na ocenie działalności jednostki gospodarczej poprzez (Analiza finansowa... 1996):

- podział zjawisk i procesów ekonomicznych na elementy składowe,

- określenie zależności przyczynowo-skutkowych pomiędzy badanymi składnikami,

- sformułowanie wniosków po przeprowadzonej ocenie porównawczej.

Analiza techniczno-ekonomiczna opiera się w głównej mierze na wielkościach ekonomicznych w wyrażeniu rzeczowym lub osobowym, a jedynie uzupełniająco prezentuje dane finansowe (Bednarski 2007).

Analiza strategiczna polega na uwzględnianiu w procesie analitycznym czynników zewnętrznych wpływających na jednostkę gospodarczą i na tej podstawie zbudowaniu planu strategicznego (Bednarski 2007).

Analiza finansowa stanowi najstarszy dział analizy ekonomicznej, choć początkowo występowała wyłącznie w praktyce, pełniąc funkcję dokumentacyjną i objaśniającą (Walczak 1998). Analiza finansowa jest podstawą oceny efektywności działalności jednostki gospodarczej oraz jej sytuacji majątkowo-finansowej (Gabrusewicz 2005), co przedstawia rys. 2.

Specyfika działania jednostek samorządu terytorialnego wynika z ich misji oraz postawionych im zadań. Przede wszystkim nie są to jednostki nastawione 
na osiąganie zysku, lecz zaspokajanie potrzeb społecznych, a ściślej - potrzeb społeczności lokalnych. Stąd też działania analityczne powinny dotyczyć analizy budżetu takiej jednostki i związanych z tym elementów. Analiza finansowa jednostkowych sprawozdań finansowych państwowych i samorządowych jednostek budżetowych oraz jednostek samorządu terytorialnego staje się pomocna w kontekście oceny skuteczności realizacji celów i sprawowania funkcji kontrolnej (Rup 2017). Klasyczne podejście do analizy finansowej oparte na ocenie efektywności oraz sytuacji majątkowo-finansowej odnosi się przede wszystkim do zakładów budżetowych (Zysnarska 2016). Rola tej analizy powinna zostać wzmocniona.

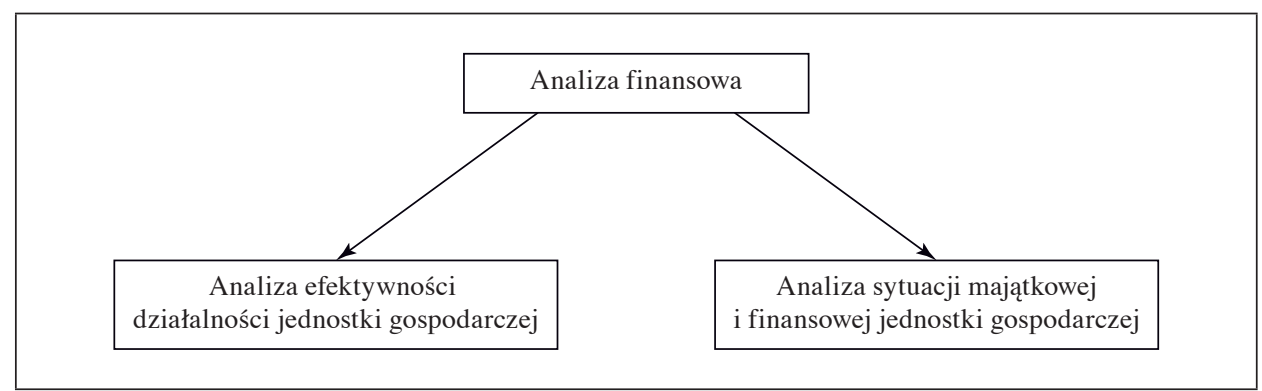

Rys. 2. Istota analizy finansowej

Źródło: opracowanie własne na podstawie (Analiza finansowa... 2003).

Analiza finansowa w jednostkach finansów publicznych, w swojej specyfice, jest narzędziem pomocnym do racjonalizowania procesu gospodarowania środkami publicznymi. Racjonalne gospodarowanie środkami publicznymi dotyczy tzw. zasady 3-E (economy, effectiveness, efficency), czyli oszczędności, efektywności i wydajności (Zysnarska 2010). Zasada ta wywodzi się z koncepcji nowego zarządzania publicznego (new public managment), która stawia na odejście od zasad i procedur związanych z dokonywaniem wydatków na rzecz wdrożenia analizy osiąganych wyników związanych z dokonywanymi wydatkami i stosowania rynkowego podejścia do świadczonych usług publicznych (Młodzik 2015).

Krytycy tej doktryny zwracają jednak uwagę na niebezpieczeństwo odejścia przy takim podejściu od efektywności jednostki w zakresie zaspokajania potrzeb społecznych na rzecz polepszenia sprawności jednostki i redukcji kosztów (Kowalczyk 2017). W literaturze przedmiotu wskazuje się na swego rodzaju dylemat: czy ważniejsza jest efektywność gospodarcza, czy sprawiedliwość społeczna? (Nestorowicz 2014). Ze względu na specyfikę jednostek sektora publicznego rynkowy model zarządzania nie jest w pełni możliwy do wykorzystania. W efekcie powstała koncepcja new public governance, oparta na administracyjno-rynkowym 
modelu zarządzania. Model ten pozwala bowiem na odpowiedni nadzór nad takimi jednostkami, z drugiej strony zapewnia elastyczność w zakresie zaspokajania zróżnicowanych i zmieniających się potrzeb społecznych (Szewczuk 2011).

W każdej ze wskazanych koncepcji narzędziem pomocnym w realizacji celów jest analiza finansowa. Przy jej dokonywaniu, poza wskazanymi wyżej okolicznościami, należy zwrócić uwagę również na odmienność źródeł finansowania w stosunku do przedsiębiorstw komercyjnych oraz ograniczenia prawne w zakresie zewnętrznych źródeł finansowania.

Analiza finansowa w jednostkach samorządu terytorialnego dotyczy:

- analizy wstępnej sprawozdań budżetowych z wykonania dochodów i wydatków oraz relacji między dochodami a wydatkami - analizy ich struktury i dynamiki,

- pogłębionej analizy wskaźnikowej budżetu.

Analiza struktury i dynamiki dochodów może być przeprowadzona przy wykorzystaniu m.in. wskaźników (Zysnarska 2016):

- struktury dochodów, co dostarcza informacji o potencjale dochodowym jednostki samorządu terytorialnego,

- dochodów własnych, co umożliwia poznanie stopnia samodzielności finansowej jednostki,

- dochodów z tytułu udziału w podatkach/dochodach budżetu państwa, co ukazuje atrakcyjność ekonomiczną jednostki i jakość życia mieszkańców,

- struktury dotacji celowych, co umożliwia analizę dochodów z określonym odgórnie przeznaczeniem,

- struktury subwencji ogólnej, co pozwala na określenie jej udziału w dochodach budżetu ogółem, jak też w poszczególnych częściach budżetowych,

- struktury rodzajowej dochodów, co umożliwia poznanie głównych źródeł pozyskania dochodów,

- struktury dochodów według klasyfikacji budżetowej, co obrazuje przedmiotowy i podmiotowy charakter powstawania dochodów,

- struktury dochodów według zadań, co umożliwia zbadanie dochodów w odniesieniu do zadań ogółem i poszczególnych zadań.

Analizę wydatków budżetowych rozpoczyna się od porównania wydatków faktycznych z założonym planem. Każde odchylenie negatywne wymaga pogłębienia analizy. Do tego celu można wykorzystać następujące wskaźniki struktury i dynamiki (Zysnarska 2016):

- wydatków budżetowych według podziału na majątkowe i bieżące, które informują o „konsumpcyjności” wydatków bieżących i potencjale rozwojowym jednostki,

- wydatków budżetu ogółem według podziałek klasyfikacji budżetowej, co prezentuje ich wielkość odpowiednio do oznaczenia podziałki, 
- udziału wydatków strukturalnych, co informuje o udziale tego typu wydatków w wydatkach ogółem, jak również ich konsumpcji,

- wydatków budżetu według kryterium kompetencyjnego, co pozwala poznać udział wydatków na zadania własne,

- wydatków bieżących według kryterium rodzajowego, co określa, jaka część wydatków budżetu przypada na poszczególne rodzaje wydatków.

Analiza relacji pomiędzy dochodami a wydatkami budżetu sprowadza się do:

- ustalenia ograniczeń prawnych przyjętych na etapie planowania budżetu i po jego wykonaniu,

- analizy struktury źródeł finansowania zadań jednostki samorządu terytorialnego.

Pierwszy element wynika z zasady, że planowane wydatki bieżące nie mogą przekroczyć planowanych dochodów bieżących powiększonych o nadwyżkę budżetową z lat ubiegłych i wolne środki. Po zakończeniu roku podlega to ocenie pod względem faktycznej realizacji.

Analiza struktury źródeł finansowania zadań jednostki samorządu terytorialnego dokonywana jest natomiast $\mathrm{z}$ wykorzystaniem wskaźników udziału źródeł finansowania w kwocie wydatków ogółem poniesionej na zadanie (Zysnarska 2016).

Pogłębieniem tej analizy jest:

- ocena atrakcyjności i potencjału finansowego jednostki samorządu, prezentująca jej zdolność do rozwoju i poziomu zaspokojenia potrzeb społeczności lokalnej,

- analiza płynności finansowej planowania i wykonania budżetu,

- analiza zadłużenia, którą przeprowadza się na podstawie ustawowo zindywidualizowanego wskaźnika zdolności kredytowej danej jednostki (Ustawa z dnia 27 sierpnia 2009 r. ...),

- analiza samodzielności finansowej, tj. analiza dysponowania dochodami i wydatkami samorządu (Zysnarska 2016).

Jednostki samorządu terytorialnego oprócz sprawozdań budżetowych przygotowują obligatoryjnie także roczne sprawozdania finansowe, które stanowią obszerne źródło informacji o tych jednostkach. Stąd oprócz analizy budżetu w jednostkach samorządu terytorialnego wykorzystuje się metody analizy sprawozdań finansowych. Taka analiza dostosowana jest do treści sprawozdania finansowego i opiera się na analizie wstępnej, czyli poziomej i pionowej poszczególnych elementów sprawozdania finansowego. Analiza pionowa dotyczy oceny struktury poszczególnych części sprawozdania finansowego, zaś analiza pozioma odnosi się do analizy dynamiki zmian poszczególnych pozycji.

Pogłębieniem analizy wstępnej jest analiza wskaźnikowa, która najczęściej wykorzystuje: 
- wskaźniki rentowności, oparte na relacji rezultatów do nakładów,

- wskaźniki obrotowości, czyli relacji pomiędzy wielkościami poszczególnych kategorii zasobów i odpowiadających im merytorycznie wielkościom strumieni (Sprawozdania finansowe... 2005),

- wskaźniki płynności finansowej, obrazujące zdolność jednostki do spłaty bieżących zobowiązań,

- wskaźniki wspomagania finansowego, prezentujące zdolność jednostki do spłaty całkowitego zadłużenia.

Wskaźniki mogą stanowić podstawę rozbudowy i stać się narzędziem kompleksowej oceny działalności jednostki w ramach układu piramidalnych wskaźników finansowych (analiza piramidalna). Przykładem takiego podejścia jest model wskaźnikowej analizy Du Ponta (Block i Hirt 1987, Gup 1987), służący do oceny zyskowności jednostki gospodarczej. Model ten eksponuje istotne związki pomiędzy wskaźnikami charakteryzującymi proces efektywnego gospodarowania. Przedstawia on równorzędność czynników zyskowności i szybkości obrotu, jak również majątkowy i kapitałowy sposób dojścia do ostatecznej efektywności (Micherda 1990). Ciekawym elementem tego modelu są wariantowe sposoby ustalania wskaźników zwrotu majątku i zwrotu majątku czystego (kapitałów własnych). Model ten wykorzystuje również tzw. arytmetykę modelową, która umożliwia budowanie interesujących konstrukcji w ramach piramidy wskaźników (Micherda 2008).

Analizę określonej kategorii finansowej można ponadto przeprowadzić, stosując metodę tzw. nierówności wzorcowych. Charakterystycznym elementem tej metody jest wyjście od oceny ogólnej i stopniowe jej pogłębianie. Algorytm tej metody sprowadza się do kilku kroków postępowania. Pierwszym z nich jest wybór syntetycznych wielkości ekonomicznych obrazujących czynniki i efekty procesu gospodarowania oraz ustalenie zależności między nimi, co pozwoli na stworzenie ciągu nierówności wzorcowej. Ciąg wzorcowy może być również zbudowany dla indeksu dynamiki wybranych zmiennych lub wskaźników odpowiednio łączących wielkości współzależne. Analiza polega na porównaniu ułożenia wybranych zmiennych rzeczywistych ze zbudowanym modelem. Zaletą tego modelu jest więc prosta interpretacja wyników. Im więcej jest bowiem niezgodności modelu rzeczywistego z modelem wzorcowym, tym bardziej niekorzystna jest ocena badanego zagadnienia. Im niezgodności położone są dalej, tym również ocena jest bardziej niekorzystna. Interpretacji modelu rzeczywistego można dokonać także z zastosowaniem tabel rankingowych.

W przypadku analizy rentowności JST należy pamiętać, że w jednostkach samorządu terytorialnego zyskowność często nie stanowi istoty działalności. Zastosowanie tego typu metod analitycznych pozwoli jednakże dokonać szerszej analizy sytuacji jednostki samorządu terytorialnego. Jest to niezwykle ważne 
z uwagi na potrzeby finansowe tych jednostek. Ze względu bowiem na wytyczone cele starają się one pozyskać dodatkowe źródła kapitału, poprzez chęć zaciągnięcia kredytów bankowych. Tego typu praktyka może spowodować konieczność wykorzystywania w działaniach analitycznych nie tylko typowej analizy wskaźnikowej, ale również modeli analizy dyskryminacyjnej, które to modele umożliwią oszacowanie prawdopodobieństwa upadłości takich jednostek. Z uwagi na zmieniającą się rzeczywistość gospodarczą jednym z istotnych problemów w dziedzinie modeli dyskryminacyjnych jest ich dezaktualizacja.

Szersze wykorzystanie metodyki analizy finansowej stosowanej w jednostkach komercyjnych uzasadnia fakt zmiany priorytetów w zakresie funkcjonowania jednostek samorządu terytorialnego. Jak wskazuje praktyka, następuje przejście $\mathrm{z}$ orientacji administrowania środkami budżetowymi na zarządzanie nimi (Kaczurak-Kozak 2016). Ocena ta powinna zatem dotyczyć efektywności gospodarowania nimi. Warto także wspomnieć o możliwości szerszego wykorzystania prospektywnej płaszczyzny analizy finansowej.

\section{Podsumowanie}

Sektor publiczny stanowi istotną część gospodarki większości krajów. Generuje on ogromne przepływy środków pieniężnych nie tylko w ramach samego sektora budżetowego, ale również dla gospodarki rynkowej. Sektor publiczny działa w permanentnym stanie braku środków pieniężnych lub niewystarczającej ich ilości. Źródła uzyskiwania dochodów nie są liczne, zaś wydatki ogromne, dlatego widoczna jest tendencja do zadłużania się podmiotów, monitorowana m.in. przez Regionalne Izby Obrachunkowe. Indywidualny wskaźnik zadłużenia wprowadzony w 2014 r. nie okazał się skutecznym narzędziem ograniczania zadłużenia. Jednostki nauczyły się omijać przepisy ustawy o finansach publicznych, stosując niezauważalne dla kontrolujących, nowoczesne instrumenty finansowe w postaci pozycji powodujących wzrost zobowiązań.

Istnieje obawa, że faktyczne zadłużenie jednostek sektora finansów publicznych jest znacznie większe niż to, które obecnie podajemy. Zagrożenie kontynuacji działalności staje się dla wielu podmiotów coraz bardziej realne.

Powinny więc istnieć narzędzia, za pomocą których możliwe będzie ocenienie faktycznej sytuacji majątkowo-finansowej. Stosowana w jednostkach budżetowych sprawozdawczość budżetowa (tzw. erbetki) oparta jest w przeważającej mierze na zasadzie kasowej, uwzględniającej faktyczne przepływy pieniężne. Co istotne, ocena dokonywana na podstawie tych sprawozdań (głównie Rb-27 i Rb-28) dotyczy krótkookresowego, rocznego planowania. 
Systemem bardziej rozwiniętej analizy powinny stać się więc sprawozdania finansowe, wykorzystywane obecnie bardzo rzadko. Ich sporządzanie traktuje się często jako konieczność wynikającą z przepisów ustawy o rachunkowości. Do zarządzania finansami stosuje się jednak sprawozdania budżetowe.

Ta sytuacja powinna ulec zmianie. Kryzys finansowy ujawnił brak skutecznych systemów i narzędzi kontroli podmiotów budżetowych. Kontrola taka może być prowadzona tylko w ramach systemu rachunkowości memoriałowej, a nie kasowej. Rachunkowość memoriałowa to powszechnie akceptowalne w Europie międzynarodowe standardy rachunkowości sektora publicznego. Polska podpisała deklaracje wprowadzenia ich modyfikacji - europejskich standardów rachunkowości sektora publicznego. Niestety w ciągu ostatnich lat niczego nie zrobiono w celu ich wprowadzenia, wprost przeciwnie - coraz częściej pojawią się głosy, aby z tego projektu się wycofać, m.in. ze względu na ogromne koszty wdrożenia tych standardów w jednostkach budżetowych.

System rachunkowości, który można by uznać za w pełni wiarygodny, umożliwiłby zwiększenie roli analizy finansowej opartej na sprawozdawczości finansowej, w pełni memoriałowej. Tylko ona uznawana jest za system informacyjny zapewniający wiarygodny obraz sytuacji finansowej i majątkowej. Analizy takie mogłyby stać się remedium na próby ukrywania zadłużenia oraz - co najważniejsze - możliwe byłoby stworzenie dzięki nim systemów ostrzegania o ewentualnym zagrożeniu kontynuacji działalności w długim okresie.

\section{Literatura}

Adamek-Hyska D. (2011), Kierunki harmonizacji rachunkowości jednostek sektora publicznego (w:) Problemy harmonizacji rachunkowości, red. A.M. Kostur, Wydawnictwo Uniwersytetu Ekonomicznego w Katowicach, Katowice.

Analiza finansowa w zarzqdzaniu przedsiębiorstwem (1996), t. I, red. L. Bednarski, T. Waśniewski, Fundacja Rozwoju Rachunkowości w Polsce, Warszawa.

Analiza finansowa w zarzqdzaniu przedsiębiorstwem (2003), red. M. Walczak, Difin, Warszawa.

Bednarski L. (2007), Analiza finansowa w przedsiębiorstwie, wyd. 5, PWE, Warszawa. Block S.B., Hirt G.A. (1987), Fundations of Financial Management, Irwin, Homewood. Gabrusewicz W. (2005), Podstawy analizy finansowej, PWE, Warszawa.

Gołębiowski B. (2016), Standaryzacja rachunkowości jednostek sektora publicznego w Unii Europejskiej (w:) Sprawozdawczość i rewizja finansowa jednostek zainteresowania publicznego. Kierunki zmian, red. M. Andrzejewski, Difin, Warszawa.

Gup B.E. (1987), Principles of Financial Management, John Wiley \& Sons, New York.

IPSAS in Your Pocket - 2017 Edition (2017), Deloitte, https://www.ifac.org (data dostępu: 4.02.2017).

Kaczurak-Kozak M. (2016), Dualizm sprawozdawczości finansowej jednostek sektora finansów publicznych, ,Finanse, Rynki Finansowe, Ubezpieczenia”, nr 2/2016, https:// doi.org/10.18276/frfu.2016.2.80/1-08. 
Kościelniak J. (2016), Wdrożenie zharmonizowanych standardów rachunkowości sektora publicznego EPSAS w Unii Europejskiej - aktualny stan prac przygotowawczych (w:) Standardy rachunkowości jednostek sektora finansów publicznych - wyzwania dla praktyki, red. D. Adamek-Hyska, E. Maćkowiak, A. Szewieczek, Wydawnictwo Uniwersytetu Ekonomicznego w Katowicach, Katowice.

Kowalczyk M. (2017), Podstawy analizy ekonomiczno-finansowej w jednostkach samorzqdu terytorialnego, Difin, Warszawa.

Micherda B. (1990), Model racjonalnej analizy Du Ponta, „Rachunkowość”, nr 10.

Micherda B. (2008), Jaka powinna być współczesna analiza rentowności?, „Rachunkowość", nr 11.

Młodzik E. (2015), Założenia koncepcji New Public Management, „Zeszyty Naukowe Uniwersytetu Szczecińskiego", nr 858.

Nesterowicz R. (2014), Ocena sytuacji finansowej sektora instytucji rzqdowych i samorzqdowych w Polsce, „Nierówności Społeczne a Wzrost Gospodarczy”, nr 4.

Niemiec R. (2017), Roczne sprawozdanie finansowe JST, „Rachunkowość Budżetowa”, nr 6.

Rozporządzenie Ministra Finansów z dnia 5 lipca 2010 r. w sprawie szczególnych zasad rachunkowości oraz planów kont dla budżetu państwa, budżetów jednostek samorządu terytorialnego, jednostek budżetowych, samorządowych zakładów budżetowych, państwowych funduszy celowych oraz państwowych jednostek budżetowych mających siedzibę poza granicami Rzeczypospolitej Polskiej, Dz.U. 2016, nr 128, poz. 861.

Rozporządzenie Ministra Finansów z dnia 2 listopada 2015 r. zmieniające rozporządzenie w sprawie szczególnych zasad rachunkowości oraz planów kont dla budżetu państwa, budżetów jednostek samorządu terytorialnego, jednostek budżetowych, samorządowych zakładów budżetowych, państwowych funduszy celowych oraz państwowych jednostek budżetowych mających siedzibę poza granicami Rzeczypospolitej Polskiej, Dz.U. 2015, poz. 1954.

Rozporządzenie Ministra Rozwoju i Finansów z dnia 29 grudnia 2016 r. zmieniające rozporządzenie w sprawie szczególnych zasad rachunkowości oraz planów kont dla budżetu państwa, budżetów jednostek samorządu terytorialnego, jednostek budżetowych, samorządowych zakładów budżetowych, państwowych funduszy celowych oraz państwowych jednostek budżetowych mających siedzibę poza granicami Rzeczypospolitej Polskiej, Dz.U. 2017, poz. 24.

Rup W. (2017), Sprawozdanie finansowe za 2016 rok: państwowych i samorzqdowych jednostek budżetowych, samorzqdowych zakładów budżetowych, jednostek samorzqdu terytorialnego, ODDK, Gdańsk.

Sprawozdania finansowe i ich analiza (2005), red. B. Micherda, Stowarzyszenie Księgowych w Polsce - Zarząd Główny, Centralny Ośrodek Szkolenia Zawodowego, Warszawa.

Sprawozdawczość finansowa i budżetowa jednostek sektora finansów publicznych (2016), red. K. Winiarska, Wolters Kluwer, Warszawa.

Szewczuk A. (2011), Filozofia nowego zarzadzania publicznego w jednostkach samorzqdu terytorialnego a praktyczne implikacje (w:) Nowe zarzqdzanie finansami publicznymi w warunkach kryzysu, red. S. Owsiak, PWE, Warszawa.

Ustawa z dnia 27 sierpnia 2009 r. o finansach publicznych, Dz.U. 2013, poz. 885, z późn. zm. Walczak M. (1998), Prospektywna analiza finansowa przedsiębiorstwa, PWE, Warszawa. 
Winiarska K., Kaczurak-Kozak M. (2013), Rachunkowość budżetowa, Oficyna a Wolters Kluwer business, Warszawa.

Zysnarska A. (2010), Rachunkowość budżetowa w świetle koncepcji prawdziwego i wiernego obrazu, Wydawnictwo Uniwersytetu Gdańskiego, Gdańsk.

Zysnarska A. (2016), Rachunkowość sektora budżetowego z elementami analizy finansowej, ODDK, Gdańsk.

\section{The Contents of Financial Statements of Public Finance Sector Units}

(Abstract)

In the majority of countries, the finance sector constitutes one of the most important parts of the economy. Public finance sector units often raise funds and spend them on non-profitable activities, however essential they may be for the proper functioning of society. The cash participating in these operations make up a significant share of the transfers of a country's entire economy. Thus, public finance sector units are required to keep books of account based on the provisions of the Accounting Act and specific legislation adapted to the specificities of the public finance sector.

One of the obligations laid down by the Accounting Act is to present financial and property standing in the form of financial statements. As far as public finance sector units are concerned, the obligation has been extended to include preparation of budget reports, the main aim of which is to present a unit's current situation with respect to its budget revenues and expenditures. The budget reporting system is currently used in the financial management of public finance sector units mainly in the short term. Financial statements, which may be the subject of financial analysis and support long-term decision making, have rarely been used.

The paper presents financial reporting of public finance sector units, the possibilities of using the International Public Sector Accounting Standards (IPSAS) in accounting, and certain aspects of financial analysis and its use.

Keywords: public sector, financial reporting, budget reporting, financial analysis. 